\title{
Compte rendu de Dumont d'Urville. Explorer and Polymath, de Edward Duyker
}

Nancy J. Pollock

\section{(2) OpenEdition \\ Journals}

Electronic version

URL: http://journals.openedition.org/jso/7520

DOI: $10.4000 /$ jso. 7520

ISSN: $1760-7256$

\section{Publisher}

Société des océanistes

Printed version

Date of publication: 31 December 2016

Number of pages: 303-307

ISSN: 0300-953x

\section{Electronic reference}

Nancy J. Pollock, "Compte rendu de Dumont d'Urville. Explorer and Polymath, de Edward Duyker», Journal de la Société des Océanistes [Online], 142-143 | 2016, Online since 31 December 2016 connection on 24 September 2020. URL : http://journals.openedition.org/jso/7520 ; DOI : https:// doi.org/10.4000/jso.7520

This text was automatically generated on 24 September 2020.

(c) Tous droits réservés 


\section{Compte rendu de Dumont d'Urville. Explorer and Polymath, de Edward Duyker}

Nancy J. Pollock

\section{REFERENCES}

Duyker Edward, 2015. Dumont d'Urville. Explorer and Polymath, University of Hawaii Press, by arrangement with Otago University Press, 664 p., 70 photos et cartes.

1 Dumont D'Urville's passion for circumnavigating the world in the 1820 s and 1830 s is clearly conveyed in Duyker's biography. D'Urville's three trans-Pacific voyages, first in La Coquille (1822-25), the second and third in the same ship but renamed L'Astrolabe (1826-27, and 1837-41) were voluminously recorded by his hand, both during long spells at sea, and when back home in Toulon and Paris. He published many volumes on his circumnavigations, all in French. Duyker's biography makes available to English speaking readers translated extracts from D'Urville's works, to remind us of his prodigious contributions to many sectors of the science of those times.

2 The biographer's stated aim is to raise awareness for English readers of D'Urville's contributions to scientific knowledge of the ocean and the lands, particularly in the Pacific. Duyker states that the many volumes of writings and reports that D'Urville has bequeathed serve to underline "one of France's foremost authors on geographical discovery and major travel writers of the nineteenth century" (p. 17); these, he argues, "serve to strengthen a French colonial impulse in other parts of the Pacific" beyond Australia and New Zealand (p. 15). He implies that the maritime geographer's work has been under utilized. Duyker struggled with D'Urville's difficult hand-written texts, while also accessing other correspondence and reports across France. These sources have added to the early travel writings about the Pacific, while D'Urville's edited specialized volumes record the scientific background to the many specimens from 
natural history that were collected by the mariner and his scientific officers. Inclusion in the biography of 57 de Sainson's illustrations, mostly coloured, heightens the reader's visual awareness of the maritime challenges that D'Urville faced in crossing the Pacific. (Many of these illustrations can be viewed on line (ww.art.com/gallery/id-a34647/louis-auguste-de-sainson-posters.htm).

The biographer follows the chronology of D'Urville's logs to provide selected translations of materials both published and unpublished that are difficult for English speaking readers to access. He provides a background to the political events in France at the time of the voyages, as well as to D'Urville's own family settings. Detail from the logs of hydrographic surveys of coastal areas of islands of the Pacific, together with naming geographic features, also provides brief references to trips ashore for gathering natural history specimens. He cites a few incidents where the Astrolabe nearly foundered due to rocky shorelines and tumultuous seas, as clearly portrayed in the artist Louis de Sainson's many (57 reprinted here) detailed lithographs.

D'Urville's major achievement, in his own view, was to find the remains of La Perouse's ship Astrolabe, wrecked off Vanikoro in the Santa Cruz Islands in 1788. That find, together with his earlier (controversial) contribution to acquiring the Venus de Milo statue for France from a Greek farmer during his first surveying expedition (1820) in the Mediterranean, and his discovery that D'Urville island is separated by French Pass from the northern tip of the south island of New Zealand should have brought him greater recognition at the time. The biography underlines the mariner's frustrations that his dedicated and patriotic contributions were under-valued by both French administrators, and the wider public.

5 This new English introduction to D'Urville's work as a maritime geographer, extends the shorter (200 page) introduction to D'Urville's voyaging in John Dunmore's From Venus to Antarctica (2007) by providing many references to D'Urville's scientific publications. D'Urville's particular interest in New Zealand, where he visited on all three voyages of the Coquille/Astrolabe, has already been translated into English in five specific publications, ranging from S.Percy Smith in the 1920s to four books since 2007, and many articles, such as that by Margaret Simpson (2008) in the Dictionary of New Zealand Biography, and a contribution to Te Ara Encyclopedia of New Zealand (http:// www.TeAra.govt/nz), not cited by the biographer. This volume provides detailed notes on French sources.

Duyker presents D'Urville the man, as a strong bibliophile, particularly in classic Greek and Roman literature, that inspired his penchant for recording his voyages in detail, as well as recognizing the contributions of his scientific officers to the voyages' natural history records. The biographer situates the explorer within an aristocratic family background, with a coterie of contacts in Paris, some very critical of his ambitions. It is clear that D'Urville was very torn by his responsibilities to his wife Adele and their children (two deceased), and his responsibilities as he interpreted them to complete his transnational survey work, and to collect botanical specimens.

7 He is portrayed as determined, taciturn, and not socially inclined, though with high expectations of recognition for himself and for his crew. He was very ambitious both for France and for himself, and a workaholic, dedicated to the task before him, as closely as weather and circumstances in the Pacific allowed. He expected that others, particularly his crew, would be similarly committed. Yet he also was sympathetic to the needs to get ashore, to replenish the ship with fresh food and water, in order to keep 
his men healthy and dedicated to the circumnavigations. Scurvy, dysentery and some deaths, afflicted the crew, as well as D'Urville himself, mainly in the western Pacific, with a few deaths. His own health became severely impaired by the privations of the voyages, particularly gout that prevented him from joining his scientific officers in the 'botanising' and other natural history endeavours that were very dear to his spirit. His social interactions both with his crew and with his hosts ashore were limited by a dour nature, that kept him enclaved in his own world much of the time. We are not told explicitly as to how he spent the many months crossing large distances of the Indian and Pacific, and Atlantic oceans, but dedication to labeling his specimens and to writing early draft reports, including his unpublished novel, must have filled those days at sea. His dedication to his family, particularly his wife Adele in Toulon, took second place to his passion to complete his circumnavigations.

He knew from reading accounts by Captain Cook and earlier voyagers that reprovisioning with fresh food was vital to the health of his crew, particularly to avoid scurvy. He sought assistance in Ambon and Hobart, for example, for hospital care for many of his crew suffering from dysentery. His own gout and stomach problems deterred him from opportunities to step ashore for his beloved 'botanising' expeditions. As captain of the Astrolabe his superior navigation skills were severely tested, especially during the close inshore survey work, where he pulled the ship from several points of near wreckage. He inspired his crew's major efforts, even to physically pulling the Astrolabe out of the surrounding ice flows in Antarctica. But he brought the Astrolabe and its crew home to Marseille with some 6000 natural history specimens, to be housed in French museums - two major feats for those times.

D'Urville's first voyage to the eastern Mediterranean in 1820 provided an apprenticeship in coastal survey techniques that prepared him for his subsequent circumnavigations, including two visits to Antarctica. His voyages to the Pacific firstly as second in command to Captain Duperrey aboard the Coquille, 1823-1825, whetted his appetite for taking sole command for a second circumnavigation, 1826-1829, ostensibly to find the remains of La Perouse's ship; he renamed the Coquille as the Astrolabe in honour of the lost French explorer and his ship. D'Urville's third voyage, 1837-1840, was under instruction from the French Marine Department to complete coastal surveys of unmarked islands, particularly northern New Guinea, and to take the two ships (Astrolabe and its accompanying Zelee) as far south into the Antarctic ice shelf, to reach 72 degrees south, if possible. 'Claiming' parts of the Antarctic ice shelf for France, was King Louis Philippe's special instruction, though the Astrolabe, together with the Zelee only reached 65 degrees 20 south before being forced to turn back by ice packs an amazing feat in wooden vessels under sail.

On all three trans Pacific voyages D'Urville visited the New Zealand coastline, as he developed a very special interest in the two islands, both for their coastal and botanical contributions, as well as a possible site for establishing a French colony. His interest in the inhabitants inspired him to write a novel, based on his first six week visit, about a conflict between two Maori chiefs. But it remained unpublished until Carol Legge addressed it in her PhD (1989) and published a translation into English: J.S.C. Dumont D'Urville, The New Zealanders; a story of Austral lands (1992). Duyker has relied for most of his Chapter 10 on New Zealand, using Legge's extensive notes to her translation. But Duyker includes reference to D'Urville's novel under D'Urville in the Archival, and 
Bibliographic souces, not under a listing for Legge. So reference to the novel is hard to find.

11 Given the voyager's interests, it is not surprising that several earlier translations into English of D'Urville's accounts of the New Zealand legs of those three voyages are readily available in local libraries around New Zealand, as well as in the Turnbull library, Wellington, where some 15 volumes under D'Urville's name are housed. Duyker's new biography provides researchers with access in English to detailed references to that work. For me, as I look across the water to D'Urville island I am led to consider the ecology that the 'botaniser' recorded for that island, particularly the varieties of ferns. The very recent release of a new edition of D'Urville's own compilation in French for popular consumption, entitled Voyage Pittoresque autour du monde...(2015) in two volumes serves to acknowledge recent interest in D'Urville's contributions to expose a wider readership to knowledge of Pacific geography and natural science.

Rosenman's two volume translation (2009) covers an Australian perspective on D'Urville's contributions to the history of explorations, particularly of Australasia. D'Urville would have welcomed this attention to his works as they spread the word of his achievements to the rest of the world.

Duyker alerts an English reading audience to D'Urville's skills in navigating a small wooden ship close in shore of small islands, many uncharted. He almost lost the ship amidst reefs and tempestuous winds while finding a way between the north and south islands of New Zealand, now named French Pass, as well as off the coast of Tongatapu in Tonga. As he tried to follow instructions from Paris to survey Torres Straits between Australia and Papua New Guinea he only just managed to extract the ships from going on the rocks. And his two visits to Antarctica, in subsequent summers, each necessitated hasty withdrawals, with his crew physically pulling the Astrolabe out of the blocking ice, as D'Urville wanted to press on to carry out orders from home to reach 72 degrees south 'for France'.

D'Urville was under strict instructions from French naval authorities as to his routes, and the timing of his stays in key locations, as well as to major intentions for each voyage (see Wright 1955 Appendix for a translation of the copy of the Letter of Intention for the second voyage). While surveying coastlines for hydrographic and bathymetric records in order to update earlier maps was a primary commitment, D'Urville was also charged by French authorities with locating La Perouse's ships, wrecked in 1788 somewhere in the southwest Pacific, and also to exploring Antarctica as far south as possible at the behest of King Louis Phillippe. The success of these challenges speaks forcibly of D'Urville's navigation skills amidst horrific tempests close in shore, being becalmed for days, and extracting his ship from the ice of Antarctica, all very treacherous situations, and all under sail. He must have held fearsome images for his own ship of what had happened to La Perouse in 1788, while reassuring his own crew that they would reach France again safely.

15 D'Urville's interests in 'botanising' along with other scientific collecting activities were also paramount. He was keen to get ashore as frequently as possible to collect specimens of flora that finally amounted to some five to six thousand species that were later deposited in French museums. The biographer gives few citations for particular species that have made special contributions to our subsequent knowledge of Pacific 
flora. It would also be useful to have an indication as to where those key specimens could be viewed by today's scientists.

The scientific officers aboard the Astrolabe added specimens of geology, entomology, mollusks, and birds to these vast collections. Each of the officers, including Jacquinot, the two Lessons, and Quoi, contributed his own 'division' to the volumes pertaining to each voyage. In addition five atlases are listed (p. 613), but their current location is not recorded. We are told that editing the final volumes, particularly the account of the third voyage, Voyage au Pole Sud... after D'Urville's death was completed by his colleagues, Jacquinot and Vincendon-Dumoulin, though they chose to attribute the volumes to D'Urville as principal author.

17 For the last voyage of the Astrolabe, D'Urville included a phrenologist, Dumoutier, in his team of scientific officers, to increase his knowledge of 'interesting objects' and human differences. Dumoutier took casts of skulls of somewhat reluctant island people, as well as taking skulls from graves on various islands for further analysis back in Paris. (Dumoutier also took casts of D'Urville's own family, and D'Urville bequeathed his own skull to the phrenologist's wider endeavours). D'Urville was interested in 'reading' the skulls as a then current scientific endeavour to distinguish human 'races'. D'Urville drew on this specialized knowledge of differences between some 50 skulls to add to his compilation of lists of words, written down mainly from information provided by Pacific island men aboard the Astrolabe. Taking these two human differentiating factors together he spoke to a Paris audience (1831) of significant differences within Oceanie between Polynesians, Micronesians, and Melanesians, as they differed from Malaysians based on an idea proposed by earlier geographers (p.305). D'Urville was neither a linguist nor a physical anthropologist but he has contributed his comparative view to establish this division of Oceanic peoples for posterity. His bequest of this tripartite division of Pacific people has become embedded in European interpretations of Pacific cultural heritage, though this biographer makes no reference to current parlance on this widely debated classification.

Recognition for his achievements by officials back in France was too slow in coming for D'Urville. Not only was his first 'major discovery' that associates him with purchasing and bringing the Venus de Milo statue back to France and the Louvre from Greece, under much debate, but his recovery of an anchor from La Perouse's ill fated voyage in a bay of Vanikoro, in the Santa Cruz islands went under-acknowledged, despite his detailed reports to French authorities in Paris. D'Urville sought recognition of the dedication and commitments of his crew with medals and promotions, but these were acknowledged too slowly by French authorities, in his view. His own personal advancements in naval and scientific circles drew less public interest than he expected. He would no doubt be delighted with the increasing interest in his work in the $21^{\text {st }}$ century, as in this biography.

19 Another charge on D'Urville's circumnavigations, though expressed in muted terms, was to maintain France's political stamp on the Pacific. One aspect of his coastal surveys was to recommend likely places where French colonies could be established, with good access from the seas, as well as to the hinterlands. He met with other colonizing expeditions in Port Jackson/Sydney, Hobart, Auckland, and Ambon, meetings that strengthened his resolve to stamp French influence across the Pacific. He arrived in the Bay of Islands in New Zealand in 1840 just when Hobson was declaring the two islands as a British colony. His instruction from French authorities weighed 
upon his mind and his discussions with other European representatives that he met in ports he visited. But his biographer does not mention the establishment of a French penal colony on New Caledonia.

D'Urville's patriotic/ geographic penchant led him to place French names on his charts, where these were missing. He inserted the names of French dignitaries, of his wife Adele, and of his own colleagues aboard the ships and back in France, as well as his own name, to headlands and bays that were unnamed on charts of the times. He wanted to use names in the local language, wherever possible (e.g, p.203), but his written versions of what he heard, such as Houa-Houa for Tolaga Bay and Chongui for the Maori chief Hongi Hika, have added to the translator's problems. D'Urville felt strongly obliged (and gratified) to amend the charts from Captain Cook's voyages, on which he was reliant, as one means of asserting French rivalry over the British explorers. Many of those French names have persisted, such as the Adelie penguin that the crew encountered in Antarctica reefs. The island off the northern tip of the South Island of New Zealand is still named D'Urville, as is the Astrolabe reef in the Bay of Islands. His stamp on the charts and maps of the Pacific islands remains, even though knowledge of the man and his ship is only vaguely recalled today.

The vast publication list of D'Urville's works reinforces his personal dedication to French scientific endeavours in the early $19^{\text {th }}$ century. The twenty five or more published documents that D'Urville wrote, or edited, during his shortened life time, indicate the extent to which the explorer was committed to adding his name to the annals of earlier circumnavigators, including Captain Cook, and French predecessors such as Bougainville and Freycinet. His early death in a train crash in 1842 that also killed his wife and son, cut short what may have been an even greater analysis of all those materials which he collated and published.

This biography of some 600 pages, thus adds a new dimension to three recent volumes on D'Urville's work in English (Dunmore 2007; Rosenman (2 volumes) 2009, and Legge's translation of D'Urville's unpublished novel (Legge 1992). It alerts us to many sources of D'Urville's own publications and those of his scientific officers. But their place in the materials on Pacific history i not identified. Notable omissions are a biographical article on Dumont D'Urville by Margaret Simpson, included in the Dictionary of New Zealand Biography (2001), nor is Olive White-Baldwin's The Story of French Pass and D'Urville island (1970), both in English. Fifty-five detailed illustrations, many hand-coloured lithographs by the artist, Louis de Sainson, accompanying D'Urville, are valuable inclusions in this volume, and also readily available for purchase on the de Sainson website. The current volume will point researchers to new aspects of Pacific environmental history through the extensive Notes (pp.511-592), and detailed listing of 'Archival, Bibliographic and Periodical sources'(pp.607-640).

Duyker's biography thus provides a selection of highlights of D'Urville's main contributions to natural history, in the early $19^{\text {th }}$ century through his collections made mainly in and around Pacific islands. It provides a strongly referenced volume to guide English speaking researchers to the extensive volumes of data that D'Urville and colleagues have bequeathed so that these can in turn be explored within modern areas of enquiry.

Duyker's volume would have benefitted from better choice of maps to guide those less familiar with the many small islands across the Pacific that D'Urville visited or sighted. 
Many versions of Pacific maps are readily available from ANU history department or University of Hawaii, for example and on line.

The biographer's choice to retain D'Urville's names for Australia, as New Holland, and Port Jackson for Sydney, may be confusing to those readers less familiar with Australasia. And the use of Ualan for a now amalgamated province of western Kosrae (pp. 148-150, and illustration) needs updating for its place in that island's and Micronesian history; it could be confused with the neighbouring atoll Ujelang in the Marshall Islands 200 miles to the east. Misspelling of Tongan and Fijian chiefs' names, such as Taufa'ahau (p.214) and Tanoa (pp.388, 389) also omitting their rankings, and use of Shongui for Hongi Heka, may cause offense to today's readers.

The absence of any record of the current location of the many artefacts that D'Urville and his crew must have collected during the voyage is a major deterrent to today's interest in the creativities of Pacific communities at contact. Citations as to the location of such objects in modern museums, whether in France or beyond, would assist those compiling such registers as Kaeppler's extensive records for many Museum collections of Captain Cook's artefacts. The biographer appends nine pages on the disposition of D'Urville's personal library after his death, but does not provide a parallel inventory for the numerous artefacts, whether in his home or in museums. These are of great interest to modern thinking about material culture within the environmental changes over the last 200 years. Discussion of the repatriation of retrieved objects such as skulls, and the Venus de Milo statue would bring this volume into the orbit of today's interests in French contributions to Pacific and world history.

Regrettably the biographer avoids situating those contributions within the scope of Pacific history. French aspects of that history well enhanced by readable brief accounts of this French maritime geographer, such as that of John Dunmore (2007) and others, have already provided some way finders to documents yet to be translated into English. This volume thus extends the record of detailed reference sources for scholars wishing to access aspects of work of a navigator who has bequeathed records of several aspects of the ecological history of parts of the Pacific almost two hundred years ago. Readers will have to uncover the location of those volumes today, in order to expand English speakers' access to works in other European languages.

Duyker's biography captures D'Urville's passions for coastal navigation, as well as for increasing scientific knowledge during the early $19^{\text {th }}$ century. A strong fervour of French patriotism lay behind many of his contributions, and the specialised interests of his colleagues. The biography highlights the many volumes that D'Urville and his officers published in the $1830 \mathrm{~s}$ and $1840 \mathrm{~s}$, that have remained largely underacknowledged. This account of D'Urville's logs of three circumnavigations, set within the political context of French contributions to knowledge, provides a useful reference work to D'Urville's varied contributions to 'travel writer's' work and various branches of scientific history of the Pacific in the early nineteenth century. 


\section{AUTHOR}

NANCY J. POLLOCK

Victoria University of Wellington, New Zealand 